Basic Health Sciences

Poster

Abstract ID: 60

\title{
Antilipase and antioxidant activity of Orthosiphon stamineus methanolic extract
}

Norsyuhada Alias ${ }^{\mathrm{a}}$ | Adam Leow Thean Chor $^{\mathrm{b}} \mid$ Mohd. Shukuri Mohamad Ali ${ }^{\mathrm{b}}$ | Abu Bakar Salleh ${ }^{\mathrm{b}}$ | Asilah Ahmad Tajudin ${ }^{\mathrm{b}}$ | Raja Noor Zaliha Raja Abd. Rahman ${ }^{\mathrm{b}}$

${ }^{a}$ Kulliyyah of Allied Health Sciences, International Islamic University Malaysia

${ }^{b}$ Enzyme and Microbial Technology Research Centre, Universiti Putra Malaysia

Introduction: Antilipase from natural resources are a potential tool for the treatment of obesity while antioxidant-rich plants are essential in combating degenerative diseases. The aim of this study is to determine the antilipase and antioxidant activity of Orthosiphon stamineus methanolic extract. Methods: The inhibitory activity against pancreatic lipase was determined by measuring the hydrolysis of p-nitrophenyl butyrate to p-nitrophenol at $405 \mathrm{~nm}$. Antioxidant activity of 0 . stamineus extract was measured by 2 , 2, diphenyl-1-picrylhydrazyl (DPPH) free radical scavenging activity assay. Results: The $O$. stamineus crude extract exhibited strong lipase inhibitory activity with an $\mathrm{IC}_{50}$ value of $34.7 \mu \mathrm{g} / \mathrm{ml}$. The inhibition mode study disclosed that $O$. stamineus could act as uncompetitive inhibitor. $O$. stamineus showed high antioxidant activity with an $\mathrm{EC}_{50}$ value of $26.3 \mu \mathrm{g} / \mathrm{ml}$. Conclusions: The results suggest that 0 . stamineus has shown potential as a source of natural antilipase and antioxidant.

KEYWORDS: Orthosiphon stamineus, antilipase, antioxidant, pancreatic lipase inhibitor 